\title{
A study the Personality and achievement Motivation of among High School Students of Jalgaon District
}

\author{
Rani Tripathi*
}

\section{ABSTRACT:}

This paper aims to study the achievement motivation and personality of high school students in relation to the type of urban and rural area. The study was conducted on 120 students (60 boys 60 girls) studying in high schools selected purposively from Jalgaon district of Maharashtra state. Intact classes of VIII to $\mathrm{X}$ were taken from the four schools. For the collection of necessary information investigator used Personality Inventory (M.P.I.) by Jalota, S.S. and Kapoor, S.D. (1975) (Hindi Version). And Achievement Motivation Test by Gopal Rao (1974). To find the significance of difference between the various groups ' $t$ ' test was applied. Results indicated that rural and urban area high school students differ significantly on Personality but gender wise and area wise students do not differ significantly on achievement motivation.

Keywords: Achievement, Motivation, Personality, High School

\section{INTRODUCTION}

High school students utilized most of their time in school environment. This is important stage of personality development of student's life as well as its motivational for achievement. Between this stage students are get efforts to develop their area of personality and achievement. Every School, High school and colleges try to provide maximum educational and personality related skills to their students but some student not shown interested for grab this opportunity, and not fulfill the expectations of their parents and educational institutes. Most of the students are not able to take proper decisions due to support, with support they drives to accomplish given task, most of students accomplished task as per their priority and values of the task and its importance. Achievement motivation concept developed by social psychologist McClelland to denote the strong urge felt by an individual or society for achievement in various aspects of life that satisfies the need of self-esteem. The achievement motive is the deciding factor in attaining success in different fields.

Personality traits referred to the stable characteristics which are psychological in nature and provide reasons for person's behavior. These traits described a person and determine his emotional, cognitive, and behavioral interpersonal, experiential, attitudinal, and motivational styles that explain behavior in different situations.

\footnotetext{
*Lecturer, Bendale Mahila Mahavidhyalay, Jalgaon
} 


\section{A study the Personality and achievement Motivation of among High School Students of Jalgaon District}

Funder (2002) described personality as pattern of thought, emotion, and behavior. Personality is a multifaceted concept which is difficult to describe. Allport (1937) and Murray (1938) defined personality but wide-ranging definitions covering all aspects like intra psychic, qualities of mind and body, relations to others, and personal goals is yet to surface. According to Hogan (1991), personality refers to the social reputation, the way an individual is perceived by others.

\section{OBJECTIVES}

The main objective of the present study is to compare Personality (neuroticism and extraversion) and Achievement Motivation among high school students on the basis of rural and urban area.

1. To study the personality and achievement motivation of among high school students.

2. To study the personality and achievement motivation with respect to male and female of among high school students.

3. To study the personality and achievement motivation with respect to high school students of rural and urban.

\section{HYPOTHESIS:}

H1. There will be significant difference between Extroversion personality trait of boys and girls of urban area.

H2. There will be significant difference between Extroversion personality trait of boys and girls of rural area.

H3. There will be significant difference between Neuroticism personality trait of boys and girls of urban area.

H4. There will be significant difference between Neuroticism personality trait of boys and girls of rural area.

H5. There will be significant difference between achievement motivation of boys and girls of urban area.

H6. There will be significant difference between achievement motivation of boys and girls of rural area.

\section{METHODOLOGY:}

\section{Sample}

The sample comprised of total 120 High School students. It includes 60 male and 60 female students were randomly chosen from the 8 th and $10^{\text {th }}$ standards of high school from the Jalgaon district. The distribution of the total sample is depicted as follows:

\begin{tabular}{|c|c|c|c|c|}
\hline \multicolumn{2}{|c|}{ Area $\rightarrow$} & Rural & Urban & Total \\
\hline \multirow{2}{*}{ Sex } & Male & 30 & 30 & 60 \\
\cline { 2 - 5 } & Female & 30 & 30 & 60 \\
\hline \multicolumn{2}{|c|}{} & 60 & 60 & 120 \\
\hline
\end{tabular}




\section{District}

\section{Research design:}

\begin{tabular}{|c|c|c|c|}
\hline \multicolumn{2}{|c|}{ Area (A) $\rightarrow$} & Rural (A1) & Urban (A2) \\
\hline \multirow{2}{*}{$\begin{array}{c}\text { Sex } \\
(B)\end{array}$} & Male (B1) & $(\mathrm{A} 1),(\mathrm{B} 1)$ & $(\mathrm{A} 2),(\mathrm{B} 1)$ \\
\cline { 2 - 4 } & Female (B2) & $(\mathrm{A} 1),(\mathrm{B} 2)$ & $(\mathrm{A} 2),(\mathrm{B} 2)$ \\
\hline
\end{tabular}

Area (A):Rural

1. Sex (B)
(A1)

:Male
Urban (A2)

(B1) Female (B2)

\section{Statistical Analysis:}

In the present study to compare the rural and urban area boys and girls on the Achievement Motivation and personality one way analysis of a range of was used. For the purpose of the analysis, t-test one way ANNOVA, Descriptive statistics statistical techniques were used. The level of significance was set at 0.05 levels.

\section{Tool Used}

The following tools were decided to be used..

1. Eysenck's Maudsley Personality Inventory (M.P.I.) by Jalota, S. S. and Kapoor, S.D. (1975) (Hindi Version). The Mandsley personality inventory (MPI) is a brief but standard as well as an easily administered and scored inventory which is design for accessing introversion and extroversion dimension of personality. It is suitable normal and abnormal adults and also for adolescents. Instead of all the 14 factors only two factors were considered viz. reserved warm hearted, obedient-assertive and shy-venturesome which was supposed to be most relevant to the study.

2. Achievement Motivation Test by Gopal Rao (1974). It was revalidated through the expert's opinion and the reliability was also found by test - retest method. In this test having 20 statements with two options is used. The General Achievement Related options are assigned a score of one where as the High Achievement Related options are assigned a score of three. The scores in this scale range from 20 to 60.

\section{DELIMITATIONS}

To study was delimited with respect to its area, design, methodology, sample, tools and techniques for the study. Some of these are mentioned below:

- The investigation was confined to the high school level only. 


\section{District}

- The present study was limited to the Jalgaon District only.

- The data was only collected by students ranging between the age group of 13 to 6 years were selected on random basis.

- The measurement of personality traits was limited only to neuroticism and extraversion traits only.

H1. There will be significant difference between Extroversion personality trait of boys and girls of urban area.

Table 1. Mean, Standard Deviations, and $t-V a l u e$ of the rural and urban area $(\mathrm{N}=30$ in Each Group) for Achievement Motivation

\begin{tabular}{|c|c|c|c|c|c|}
\hline Group & $\mathbf{N}$ & Mean & S.D. & 't' & Remarks \\
\hline Boys & 30 & 28.66 & 7.63 & \multirow{2}{*}{4.61} & $\begin{array}{c}\text { Significant } \\
*\end{array}$ \\
\hline Girls & 30 & 19.9 & 5.87 & & \\
\hline
\end{tabular}

* Significant at .05 Level.

The above table no. ' 1 ' shows the descriptive statistics of the personality. The Mean of boys 28.66 and for girls 19.9, whereas for male S.D. 7.63 and S.D. for girls 5.87, obtained t-value is 4.61 which is found significant at 0.05 level. Therefore, it can be concluded that the H02 "There will be significant difference between Extroversion personality trait of boys and girls of urban area." is selected.

H2. There will be significant difference between Extroversion personality trait of boys and girls of rural area.

Table 2. Mean, Standard Deviation, and $t$-Value of the rural and urban area $(N=30$ in Each Group) for Personality

* Significant at .05 Level.

\begin{tabular}{|c|c|c|c|c|c|}
\hline Group & N & Mean & S.D. & 't' & Remarks \\
\hline Boys & 30 & 12.6 & 4.31 & \multirow{2}{*}{6.78} & $\begin{array}{c}\text { Significant } \\
*\end{array}$ \\
\hline Girls & 30 & 19.86 & 5.29 & & $*$ \\
\hline
\end{tabular}

The above table no. '2' shows the descriptive statistics of the personality. The Mean of boys 12.6 and for girls 19.86, whereas for male S.D. 4.31 and S.D. for girls 5.29, obtained t-value is 6.78 which is found significant at 0.05 level. Therefore, it can be concluded that the H02 "There will be significant difference between Extroversion personality trait of boys and girls of rural area." is selected. 


\section{District}

H3. There will be significant difference between Neuroticism personality trait of boys and girls of urban area.

Table 3. Mean, Standard Deviation, and $t$ Value of the rural and urban area $(N=30$ in Each Group) for Achievement Motivation

* Significant at .05 Level.

\begin{tabular}{|c|c|c|c|c|c|}
\hline Group & $\mathbf{N}$ & Mean & S.D. & 't' & Remarks \\
\hline Boys & 30 & 18.66 & 5.43 & \multirow{2}{*}{1.97} & $\begin{array}{c}\text { Significant } \\
*\end{array}$ \\
\hline Girls & 30 & 21.33 & 4.87 & & \\
\hline
\end{tabular}

The above table no. ' 3 ' shows the descriptive statistics of the personality. The Mean of boys 12.6 and for girls, whereas for male S.D. 4.31 and S.D. for girls 5.29, obtained t-value is 6.78 which is found significant at 0.05 level. Therefore, it can be concluded that the H02 "There will be significant difference between Neuroticism personality trait of boys and girls of urban area." is selected.

H4. There will be significant difference between Neuroticism personality trait of boys and girls of rural area.

Table 4. Mean, Standard Deviations, and $t$ Value of the rural and urban area $(N=30$ in Each Group) for Achievement Motivation

* Significant at .05 Level.

\begin{tabular}{|c|c|c|c|c|c|}
\hline Group & $\mathbf{N}$ & Mean & S.D. & 't' & Remarks \\
\hline Boys & 30 & 18.83 & 12.16 & \multirow{2}{*}{.33} & $\begin{array}{c}\text { Significant } \\
*\end{array}$ \\
\hline Girls & 30 & 19.86 & 10.81 & & $*$ \\
\hline
\end{tabular}

The above table no. ' 4 ' shows the descriptive statistics of the personality. The Mean of boys 12.6 and for girls, whereas for male S.D. 4.31 and S.D. for girls 5.29, obtained t-value is 6.78 which is found significant at 0.05 level. Therefore, it can be concluded that the H02 "There will be significant difference between Neuroticism personality trait of boys and girls of rural area" is selected.

H5. There will be significant difference between achievement motivation of boys and girls of urban area.

Table 5. Mean, Standard Deviations, and $t$ Value of the rural and urban area $(N=30$ in Each Group) for Achievement Motivation

* Significant at .05 Level.

\begin{tabular}{|c|c|c|c|c|c|}
\hline Group & $\mathbf{N}$ & Mean & S.D. & 't' & Remarks \\
\hline Boys & 30 & 40.06 & 7.05 & \multirow{2}{*}{1.74} & $\begin{array}{c}\text { Significant } \\
*\end{array}$ \\
\hline Girls & 30 & 43.13 & 5.21 & & $*$ \\
\hline
\end{tabular}




\section{A study the Personality and achievement Motivation of among High School Students of Jalgaon District}

The above table no. ' 5 ' shows the descriptive statistics of the personality. The Mean of boys 12.6 and for girls, whereas for male S.D. 4.31 and S.D. for girls 5.29, obtained t-value is 6.78 which is found significant at 0.05 level. Therefore, it can be concluded that the H02 "There will be significant difference between achievement motivation of boys and girls of urban area." is selected.

H6. There will be significant difference between achievement motivation of boys and girls of rural area.

Table 6. Mean, Standard Deviations, and $t$ Value of the rural and urban area $(N=30$ in Each Group) for Achievement Motivation

\begin{tabular}{|c|c|c|c|c|c|}
\hline Group & N & Mean & S.D. & 't' & Remarks \\
\hline Boys & 30 & 41.33 & 7.02 & \multirow{2}{*}{0.76} & $\begin{array}{c}\text { Not } \\
\text { Significant } \\
*\end{array}$ \\
\hline Girls & 30 & 42.66 & 7.28 & & \begin{aligned}$* \\
$\hline\end{aligned}
\end{tabular}

* Significant at .05 Level.

The above table no. ' 6 ' shows the descriptive statistics of the personality. The Mean of boys 12.6 and for girls, whereas for male S.D. 4.31 and S.D. for girls 5.29, obtained t-value is 6.78 which is found significant at 0.05 level. Therefore, it can be concluded that the $\mathrm{H} 02$ "There will be significant difference between achievement motivation of boys and girls of rural area." is rejected.

\section{DISCUSSION}

Personality and achievement of among High School Students of Jalgaon District were found significant. The finding of this study is supported by Vijaylaxmi and Natesan (1992) found that girl learners showed, a higher mean academic achievement motivation and achievement in comparison to boy learners. Joshi (2000) found that significant difference existed between girls of urban and rural area on neuroticism, extroversion and academic achievement.

Whereas, Ahmed (1998) found that there was no significant influence of gender on achievement motivation. Few studies showed positive relationship between academic achievement and different personality factors as Rajiv (1983), Multivariate analysis provided evidence that a student's personality and achievement, in particular the secondary school if get right direction and guidance then it will more helpful to increase level of motivation and personality development. On the other hand, students who try to developed their personality as better than others may be get positive confident and motivate for high achievement. A well personality helps to motivate better achievement and future success. 


\section{A study the Personality and achievement Motivation of among High School Students of Jalgaon District}

\section{CONCLUSION}

The findings of the study revealed that academic climate have a strong and significant effect on personality of high school students. Excellent high school environment builds effective personality and motivate for high achievement, while poor high school environment lead deprived personality and achievement motivation among high school students. The study also explored in detail the congruence between personality and achievement motivation of the students. Significant difference ware found in Achievement Motivation of boys and girls, significant difference was found in rural and urban area. Positive correlation was found between Personality and Achievement Motivation in High School boys and girls. The findings of the study may be helpful in better understanding for students and Psychologist; school counselors and also provide a practical guide for the educational policy makers.

\section{REFERENCES}

1. Adler, A. "Understanding Human Nature" New York, Grunbung publishing. ING. 1927.

2. Ahmed, J. (1998). Achievement Motivation Differences among Adolescent Boys and Girls of Various Ordinal Birth Position. Indian Psychological Review., 50(1): 2-5.

3. Gopal Rao (1974). Manual for achievement motivation test. Agra Psychological Research Cell, Agra.

4. International Journal Of Behavioral Social And Movement Sciences (ISSN: 2277-7547) Vol.02,July2013,Issue03

5. IOSR Journal of Humanities and Social Science (IOSR-JHSS) Volume 19, Issue 5, Ver. V (May. 2014), PP 57-62 e-ISSN: 2279-0837, p-ISSN: 2279-0845. www.iosrjournals.org

6. Jalota, S. and Kapoor, S. D. "Manual of Directions and Norms for Hindi and Punjabi versions of the Eysenck's Maudsley Personality Inventory (E. M. P. I.)" New Delhi: The Psycho Centre, (1975).

7. Joshi, G. (2000), Neuroticism, extraversion and academic achievement as related to gender and culture. Indian Psychological Review, 54(1-2): 74-78.

8. Sandhya G. \& Aruna S. (2013) A Correlation Study of Personality Characteristics, Academic Achievement Motivation, Educational Aspiration and Adjustment of Secondary School Students. VOL. II/VIII www.srjis.com (35-45)

9. Scholarly Research Journal for Interdisciplinary studies/Renu (1227-1232) MAR/APR2013, VOL-I, ISSUE- V www.srjis.com 1227

10. Vijayalaxmi, N. and Natesan, H. (1992), Factors Influencing Academic Achievement. Research High., 2: 62.

\section{INTERNET SOURCES}

www.google.com | www.icssr.org | www.indabook.org | www.iosrjournals.org | www.ncert.nic.in |www.oppapers.com | www.wikipedia.org | www.worlib.org 